\title{
Use of artificial neural networks for predicting volume of forest species in the Amazon Forest
}

\author{
Uso de redes neurais artificiais na predição do volume de espécies florestais na \\ Amazônia
}

Douglas Valente de Oliveira ${ }^{1}$ (D), Rafael Rode ${ }^{2}$ (D), Ricardo Rodrigues de Oliveira Neto ${ }^{1}$ (D), João Ricardo Vasconcellos Gama² (D), Helio Garcia Leite ${ }^{1}$ (D)

${ }^{1}$ Universidade Federal de Viçosa - UFV, Viçosa, MG, Brasil

¿Universidade Federal do Oeste do Pará - UFOPA, Santarém, PA, Brasil

\begin{abstract}
How to cite: Oliveira, D. V., Rode, R., Oliveira Neto, R. R., Gama, J. R. V., \& Leite, H. G. (2021). Use of artificial neural networks for predicting volume of forest species in the Amazon Forest. Scientia Forestalis, 49(131), e3610. https://doi.org/10.18671/scifor.v49n131.02
\end{abstract}

\begin{abstract}
The objective of this study was to evaluate the efficiency of artificial neural networks to predict wood volume of forest species in the Tapajós National Forest (Amazon) compared to the Schumacher and Hall volumetric model. We used data from two Units of Annual Production (UAP) of a Sustainable Management Plan in an Ombrophilous Dense Forest in the municipality of Belterra, Pará, where the Tapajós National Forest (FLONA Tapajós) is located. The data were obtained from 3607 trees of 31 species, felled and processed to obtain their commercial volume. The logarithmic form of Schumacher and Hall's model was adjusted for each UAP and $d b h$ class (two $d b h$ classes). The input variables for training the artificial neural networks (ANN) were $d b h$ and $\mathrm{h}$ as continuous variables and UAP and tree species as categoricals. The output was the commercial wood volume of a tree. We trained Multi-Layer Perceptron (MLP) neural using a resilient propagation algorithm and the sigmoid activation. The efficiency and accuracy obtained using ANN was proved based on some usual validation statistics and residual plots. The statistical analysis of the regression and ANN showed that both methods were satisfactory, but the ANN generated lower RMSE\% and higher correlation in the training and generalization. The estimates of commercial tree volume of forest species in the Amazon Forest can be obtained accurately and without bias using artificial neural networks (ANNs).
\end{abstract}

Keywords: Artificial intelligence; Precision forestry; Volumetric modeling.

\section{Resumo}

O objetivo deste estudo foi avaliar a eficiência de redes neurais artificiais na predição do volume de madeira de espécies florestais presentes na Floresta Nacional do Tapajós (Amazônia), em relação ao modelo volumétrico de Schumacher e Hall. Os dados foram obtidos em duas Unidades de Produção Anual (UPA) de um Plano de Manejo Sustentável localizado em uma área de Floresta Ombrófila Densa, no município de Belterra, Pará, onde se encontra a Floresta Nacional do Tapajós (FLONA Tapajós). Foram obtidos e utilizados dados de 3607 árvores de 31 espécies, abatidas e processadas para obtenção do volume comercial. O modelo de Schumacher e Hall, na sua forma logarítmica, foi ajustado por UPA e classes de dap (duas classes de dap). As variáveis de entrada para o treinamento de redes neurais artificiais (RNA) foram o dap, h, UPA e espécie, sendo essas duas últimas categóricas. A variável de saída foi o volume comercial da árvore. Foram treinadas redes Multi Layer Perceptron (MLP), com função de ativação sigmoide, sendo o treinamento feito pelo algoritmo resilient propagation. A eficiência e maior exatidão das estimativas de volume obtidas com o emprego de RNA foi comprovada, com base em algumas estatísticas usuais de validação e em gráficos de resíduos. A análise estatística das equações e

Financial support: None

Conflict of interest: Nothing to declare.

Correspondig author: douglasvalenteoliveira@hotmail.com

Received: 10 September 2020.

Accepted: 3 November 2020.

Editor: Paulo Henrique Müller Silva.

(c) (i) This is an Open Access article distributed under the terms of the Creative Commons Attribution License, which permits unrestricted use,

c) distribution, and reproduction in any medium, provided the original work is properly cited. 
das redes mostrou que ambos os métodos aplicados foram satisfatórios, porem as RNA, apresentaram menor RQEM\% e maior correlação tanto no treino quanto na generalização. Estimativas do volume comercial de árvores florestais na Floresta Amazônica podem ser obtidas com precisão e sem viés usando redes neurais artificiais (RNA).

Palavras-chave: Inteligência artificial; Manejo de precisão; Ajuste volumétrico.

\section{INTRODUCTION}

The abundance of forests in the Amazon always attracts the interest of loggers, cattleman and farmers seeking quick and easy profit (Veríssimo \& Pereira, 2014), thru predatory deforestation with clandestine loggers successively harvesting trees in the forest aiming to remove high-value noble woods. After 10 to 15 years of this the forest is severely degraded and quickly is completely cleared for livestock and agriculture (Celentano et al., 2012; Scheneider et al., 2000).

According to estimates from the National Forest Information System, in 2017 Brazil had 94,639 million cubic meters of wood from native forests, of which $89 \%$ were from the Amazon Forest (Sistema Nacional de Informações Florestais, 2017).

To guarantee the continuous production of wood with sustainability (economic, social and environmental), forest management is the main tool (Gama et al., 2005). In such practice, forest harvesting is carried out sustainably to produce direct and indirect products, services or benefits, together with ecosystem conservation (Campos \& Leite, 2017).

To develop and implement a Forest Management Plan it is necessary to quantify the tree wood volume of different commercial species (Thaines et al., 2010) and this is usually done using regression models fitted for species, groups of species, and locations (Tonini \& Borges, 2015). The large number of species of different ages, types and stem shapes makes sampling difficult for fitting volumetric models (Gomes et al., 2018). Fitting species- and site-specific volumetric models require enough tree samples in each stratum, resulting in high sampling effort and cost (Thomas et al., 2006).

An alternative for tree volume modeling is using artificial intelligence methods, such as artificial neural networks (ANN) (Abreu et al., 2017). This method has been used in various studies, both in even- and uneven-aged stands (Cordeiro et al., 2015; Miguel et al., 2015; Reis et al., 2018; Rocha et al., 2018; Santos et al., 2018).

Using ANN to estimate tree volume in uneven-aged stands may result in greater accuracy (Campos \& Leite, 2017) and requires less samples than volumetric models (Ribeiro et al., 2016; Vendruscolo et al., 2017).

Several studies have been made to evaluate the efficiency of ANN predicting tree volume, especially in even-aged stands (Binoti et al., 2014a, b; Gorgens et al., 2014), but studies are scarcer in uneven-aged stands with multiples species. Examples of ANN applications for tree volume prediction are found in Araújo et al. (2015), for different forest formations in the state of Minas Gerais, Lacerda et al. (2017), to estimate tree volume in the Cerrado, and in Ribeiro et al. (2016) to estimate volume of stems and branches in the Tapajós National Forest.

In this study, we evaluated the efficiency of ANN compared to a linear regression model in predicting the commercial tree volume of different forest species in the Tapajós National Forest.

\section{MATERIAL AND METHODS}

The study area is in the municipality of Belterra, in the Tapajós National Forest (FLONA Tapajós), highway BR-163 (Figure 1). The climate in this region is classified according to Köppen as $A m$, with an average rainfall of $1743 \mathrm{~mm}$ and an average annual temperature of $25^{\circ} \mathrm{C}$. The soil is predominantly Ferralsols (WRB/FAO) (Espírito-Santo et al., 2005). 


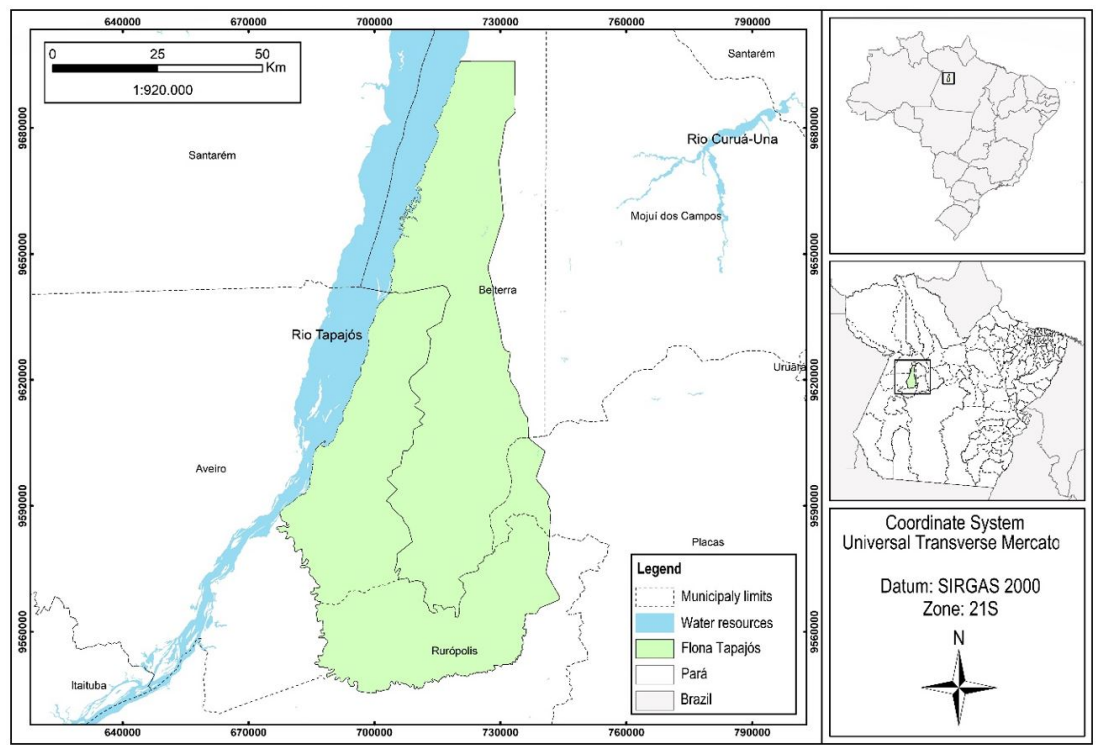

Figure 1. Location map of the Tapajós National Forest.

The FLONA Tapajós is a federal conservation unit created by Decree No. 73,684/1974. It is located in the western region of Pará, with an area of 527,000 hectares, covering the municipalities of Santarém, Aveiro, Belterra, Placas and Rurópolis. The main access ways are the Tapajós River and by Highway BR-163. Administrated by the Chico Mendes Institute for Biodiversity Conservation - ICMBio, this unit is a reference in Brazil and Latin America for socio-environmental management, sustainable use and scientific research (Instituto Brasileiro do Meio Ambiente e dos Recursos Naturais Renováveis, 2004).

Since 2005 the Tapajós National Forest Mixed Cooperative (COOMFLONA) holds the concession for commercial exploitation of the FLONA Tapajós through a community sustainable forest management plan (SFMP). Thus, the data used in this research came from rigorous tree scaling obtained from the COOMFLONA of two UAP commercially managed in the years 2008 (UAP 3) and 2012 (UAP 7), which is updated after each harvest in the UAP with diameter and length measurements of all extracted logs in the area. In addition to the measurements, logs were identified for control in the logging chain of custody. (Santos et al., 2018).

The commercial height of the trees was obtained by summing the length of the log sections. There were 1009 trees in UAP 3 and 2598 in UAP 7, with 30 forest species being represented (Table 1).

Table 1. Tree species identification and the number of trees for each Unity of Annual Production (UAP).

\begin{tabular}{cccc}
\hline Common name & Scientific name & UAP 3 & UAP 7 \\
\hline Angelim Pedra & Hymenolobium petraeum Ducke & 10 & 51 \\
Breu Amescla & Trattinnickia rhoifolia Willd. & 6 & 29 \\
Cedro vermelho & Cedrela odorata L. & 9 & 3 \\
Cedrorana & Cedrelinga catenaeformis Ducke & 40 & 106 \\
Currupixá & Micropholis melinoniana Pierre & 6 & 0 \\
Fava amargosa & Vatairea paraensis Ducke & 6 & 0 \\
Fava parica & Schizolobium amazonicum Huber ex. Ducke & 0 & 11 \\
Fava timbauba & Enterolobium maximum Ducke & 0 & 1 \\
Fava timborana & Pseudopiptadenia psilostachya (Benth.) G.P.Lewis \& L.Rico & 0 & 57 \\
Fava tucupi & Parkia mulijuga Benth. & 0 & 57 \\
\hline
\end{tabular}


Table 1. Continued...

\begin{tabular}{|c|c|c|c|}
\hline Common name & Scientific name & UAP 3 & UAP 7 \\
\hline Garapeira & Apuleia moralis Spruce ex Benth. & 13 & 35 \\
\hline Goiabão & Planchonella pachycarpa Pires & 23 & 0 \\
\hline Ipê amarelo & Tabebuia serratifolia (Vahl) Nichols. & 0 & 8 \\
\hline Ipê roxo & Tabebuia incana A.Gentry & 12 & 0 \\
\hline Itaúba & Mezilaurus itauba (Meisn.) Taub. ex Mez & 22 & 90 \\
\hline Jarana & Lecythis lurida (Miers) S.A.Mori & 121 & 435 \\
\hline Jatobá & Hymenaea courbaril L. & 76 & 171 \\
\hline Jutai mirim & Hymenaea parvifolia Huber & 0 & 72 \\
\hline Louro preto & Ocotea baturitensis Vattimo & 44 & 45 \\
\hline Louro Rosa & Ocotea sp. & 30 & 123 \\
\hline Louro vermelho & Ocotea rubra Mez. & 12 & 0 \\
\hline Maçaranduba & Manilkara huberi (Ducke) Chevalier & 274 & 520 \\
\hline Muiracatiara & Astronium lecointei Ducke & 122 & 266 \\
\hline Muirapiranga & Eperua schomburgkiana Benth. & 4 & 0 \\
\hline Quaruba & Vochysia maxima Ducke & 7 & 197 \\
\hline Sapucaia & Lecythis pisonis Cambess. & 8 & 26 \\
\hline Sucupira Amarela & Bowdichia nítida Spruce ex. Benth & 3 & 15 \\
\hline Sucupira Preta & Diplotropis purpúrea (Rich.) Amshoff & 2 & 0 \\
\hline Tatajuba & Bagassa guianensis Aubl. & 18 & 0 \\
\hline Tauari & Couratari guianensis Aubl. & 101 & 280 \\
\hline Virola & Virola melinonii (R.Benoist) A.C.Sm. & 40 & 0 \\
\hline Total & & 1009 & 2598 \\
\hline
\end{tabular}

Tree volumes were calculated using the Smalian formula. The lengths of the sections were: T1 - log total length; T2 - $2.0 \mathrm{~m} ; \mathrm{T} 3-2.5 \mathrm{~m}$; T4 - $3.0 \mathrm{~m}$; T5 - $3.5 \mathrm{~m}$ e T6 $-4.0 \mathrm{~m}$ (Ribeiro et al., 2014) (Figure 2).

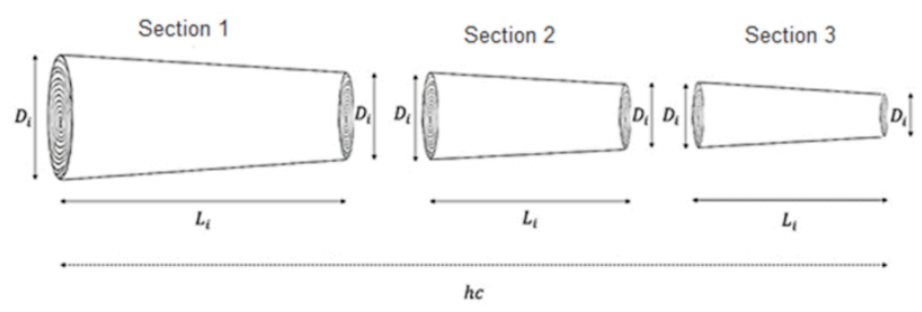

Figure 2: Scheme of a felled stem for tree scaling.

We used the regression model of Schumacher \& Hall (1933) (1), in its approximative form:

$\operatorname{LnV}=\beta_{0}+\beta_{1} \operatorname{Lndbh}+\beta_{2} \operatorname{Ln}(h)+\varepsilon ，$

Where: 
$V$ : Stem commercial volume $\left(\mathrm{m}^{3}\right)$;

$d b h$ : diameter at $1.3 \mathrm{~m}$ above ground $(\mathrm{cm})$;

$h$ : commercial height $(\mathrm{m})$;

$\beta_{\mathrm{i}}$ : model parameters;

$\varepsilon$ : random error.

Ln: neperian logarithm

The data from UAP 3 were split into two subsamples, one for $50 \leq d b h<100 \mathrm{~cm}$ and 100 $\leq d b h<174 \mathrm{~cm}$. For UAP 7 there was no need for the pre-stratification of data due to the range of the diameter distribution.

We tested five configurations of multi-layer perceptron networks with one hidden layer and using five different combinations of input variables (Table 2 ) to predict tree volume. The input variables were commercial height $(h)$ and diameter measured at $1.3 \mathrm{~m}$ above ground $(d b h)$, with UAP and tree species as categorical variables and the output was the commercial outside-bark stem volume. For each set of input variables, 50 ANN were trained.

Table 2. Data and variables used for training the neural network and the number of neurons in the hidden layer.

\begin{tabular}{|c|c|c|c|c|}
\hline Network & UAP & Quantitative variables & $\begin{array}{c}\text { Qualitative } \\
\text { variables }\end{array}$ & $\begin{array}{l}\text { Neurons in the hidden } \\
\text { layer }\end{array}$ \\
\hline 1 & $3<100$ & \multirow{4}{*}{$d b h$ e $h$} & \multirow{4}{*}{ Species } & \multirow{4}{*}{6} \\
\hline 2 & $3 \geq 100$ & & & \\
\hline 3 & 7 & & & \\
\hline 4 & 3 and 7 & & & \\
\hline 5 & 3 and 7 & $\begin{array}{l}d ; d m a x, d m e a n, d m i n, \text { / species } \\
h ; h m a x, h m e a n, h m i n \text { / species }\end{array}$ & Species & 18 \\
\hline 6 & 3 and 7 & $\begin{array}{l}d ; d \text { max }, d m e a n, d \min / \text { species } \\
h ; \text { hmax, hmean, hmin / species }\end{array}$ & $\begin{array}{l}\text { UAP and } \\
\text { species }\end{array}$ & 22 \\
\hline 7 & \multirow{2}{*}{3 and 7} & $d b h$ & UAP and & 9 \\
\hline 8 & & $d b h$ e $h$ & species & 12 \\
\hline
\end{tabular}

$d$ = individual tree diameter, $d$ max $=$ maximum diameter by species, $d$ mean $=$ mean diameter by species, $d$ min $=$ minimum diameter by species, $h=$ individual tree height, $h$ max = maximum height by species, $h m a n=$ mean height by species, $h$ min $=$ minimum height by species.

Subsequently, the data were separated by UAP and diameter class, and three other configurations were trained (For UAP 3 with $50 \leq d b h<100 \mathrm{~cm}$, UAP 3 with $100 \leq d b h<174 \mathrm{~cm}$ and for UAP 7). In each case we trained 50 RNA and used the three best networks for comparisons with the volumetric equations.

We used the logistic sigmoid activation function in the hidden and output layers (Riedmiller \& Braun, 1993). The stopping criteria were reaching the mean error of 0.001 or 3000 cycles, that is, network training was completed when one of these criteria was met. The networks were trained using the NeuroForest software (NEUROFOREST 4.0).

The statistics we used for comparisons between regression and ANN, and among ANN structures, were the correlation between the observed and the corresponding estimated (for regression) or predicted (for ANN) volumes $\left(r_{Y \bar{Y}}\right)(2)$ and the root mean square error (RMSE\%) (3), relative to the mean observed volume. We also analyzed the graphs of the relative errors (4) of estimated (or predicted) volumes (Islam et al., 2009), where:

$$
r_{y \hat{y}}=\frac{n^{-1} \sum_{i=1}^{n}\left(\widehat{Y}_{i}-\widehat{Y}_{m}\right)\left(Y_{i}-\bar{Y}\right)}{\sqrt{n^{-1} \sum_{i=1}^{n}\left(\widehat{Y}_{i}-\widehat{Y}_{m}\right)^{2} n^{-1} \sum_{i=1}^{n}\left(Y_{i}-\bar{Y}\right)^{2}}}
$$




$$
\begin{aligned}
& R M S E \%=\frac{100 \sqrt{\frac{\sum_{i=l}^{n}\left(\hat{Y}_{i}-Y_{i}\right)^{2}}{n}}}{\frac{\sum_{i=I}^{n}\left(Y_{i}\right)}{n}} \\
& R E_{\%}=\frac{\hat{Y}_{i}-Y_{i}}{Y_{i}} \times 100
\end{aligned}
$$

where: $y_{i}$ and $\hat{y}_{i}$ are the commercial observed and estimated volumes respectively, and $n$ is the number of observations.

\section{RESULTS AND DISCUSSION}

The estimates of RMSE\% and $r_{Y \bar{\gamma}}$ are presented in Table 3. The ANNs in this table were selected using these two statistics and the graphical analysis of the relative errors. The statistical analysis of the regression and ANN showed that both methods were satisfactory, but the ANN generated lower RMSE\% and higher correlation in the training and generalization.

Regarding the equations, the UAP 7 showed better results, with lower RMSE\% (20.02\%) and higher correlation (0.93). However, the efficiency was not the same in the generalization. On the other hand, for the UAP $3 \geq 100$, worse statistics were obtained in the training compared to the UAP 7, but with good generalization.

Ribeiro et al. (2016) found similar correlation values to estimate stem and branch volume in the Tapajós Flona using the Schumacher and Hall model, showing that data stratification by size classes can improve estimates. This was also observed in this study.

Only one ANN was efficient to predict volumes of the two UAP. Among the ANN stratified by diameter class, the ANN 2 which uses $d b h, h$ and species as input variables, resulted in higher accuracy (lower RMSE\%) and a higher correlation between observed and predicted volumes. For UAP 3 and UAP 7, the ANN-8 with $d b h, h$, UAP and species as input variables resulted in greater accuracy and correlation between observed and predicted volumes. The ANN-7, trained without the variable $h$ resulted in lower accuracy, demonstrating that this variable is essential for the estimation or prediction of commercial volume (Table 3).

Table 3. Estimates of linear correlation $\left(r_{\hat{y}}\right)$ between observed volumes and estimated (regression) or predicted

\begin{tabular}{|c|c|c|c|c|c|}
\hline \multirow{2}{*}{ Method } & \multirow{2}{*}{ Stratum } & \multirow{2}{*}{$\begin{array}{c}\text { Training } \\
\text { RMSE (\%) }\end{array}$} & \multicolumn{3}{|c|}{ Validation } \\
\hline & & & $r_{y y}$ & RMSE (\%) & rŷy \\
\hline \multirow{4}{*}{ Regression* } & UAP $3<100$ & 23.05 & 0.85 & 22.52 & 0.84 \\
\hline & UAP $3 \geq 100$ & 20.92 & 0.85 & 20.76 & 0.81 \\
\hline & UAP 7 & 20.02 & 0.93 & 29.17 & 0.87 \\
\hline & 1 & 17.62 & 0.91 & 28.33 & 0.89 \\
\hline \multirow{7}{*}{ ANN } & 2 & 11.42 & 0.96 & 26.75 & 0.90 \\
\hline & 3 & 17.60 & 0.95 & 27.19 & 0.89 \\
\hline & 4 & 18.92 & 0.94 & 21.38 & 0.92 \\
\hline & 5 & 18.04 & 0.95 & 21.66 & 0.92 \\
\hline & 6 & 18.09 & 0.95 & 21.37 & 0.92 \\
\hline & 7 & 25.62 & 0.89 & 28.52 & 0.86 \\
\hline & 8 & 18.00 & 0.95 & 21.57 & 0.92 \\
\hline
\end{tabular}
(RNA) volumes and the root mean square error (RMSE) obtained with the training and validation data.

${ }^{*} \mathrm{LnV}=-7.841340+1.464317 \mathrm{Lndap}+1.008576 \operatorname{Ln} h(\mathrm{UAP} 3<100) ; \operatorname{LnV}=-8.27665+1.669278 \mathrm{Lndap}+0.889781 \mathrm{Ln} h$

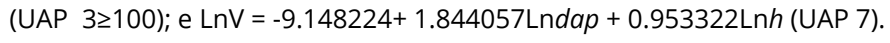

Binoti et al. (2014a) found that ANN of complex structures are not necessary for tree volume prediction. In this study, the inclusion of more variables also did not increase the 
accuracy of commercial volume estimates. In the application of ANN it is recommended to use the simplest configurations as possible, with the smallest number of neurons in the hidden layer, to facilitate the process of searching and optimizing the configuration for a network (Leite et al., 2016; Tavares Júnior et al., 2019).

The use of ANN diminishes the processing effort, ensuring its practicality (Reis et al., 2019) and may result in a greater accuracy than volumetric equations (Lopes et al., 2020). Abreu et al. (2017) also verified that ANN and support vector machines, with the categorical input variable species, yielded better results when estimating the stem volume in the Semideciduous Seasonal Forests.

The graphical analyzes of the relative errors obtained with equations and with the ANN is presented in Figure 3. We observed that the ANN always had a better data fit compared to the Schumacher and Hall model.

The ANNs 1,2 and 3, trained with the same stratification used to adjust the volumetric models, resulted in a better distribution of the relative errors. The ANN 8, trained with the grouped data, results in acceptable accuracy with no bias in the estimates, being the best ANN among those trained with the grouped data of the two UAP. The ANN 7 showed the worst results, confirming that height is an essential variable to estimate volume. (Figure 3).

The ANN is more efficient than regression analysis since the latter generates a greater dispersion in the data with a strong tendency to overestimate the tree volumes in unevenaged population, particularly for smaller volumes (Ribeiro et al., 2016).
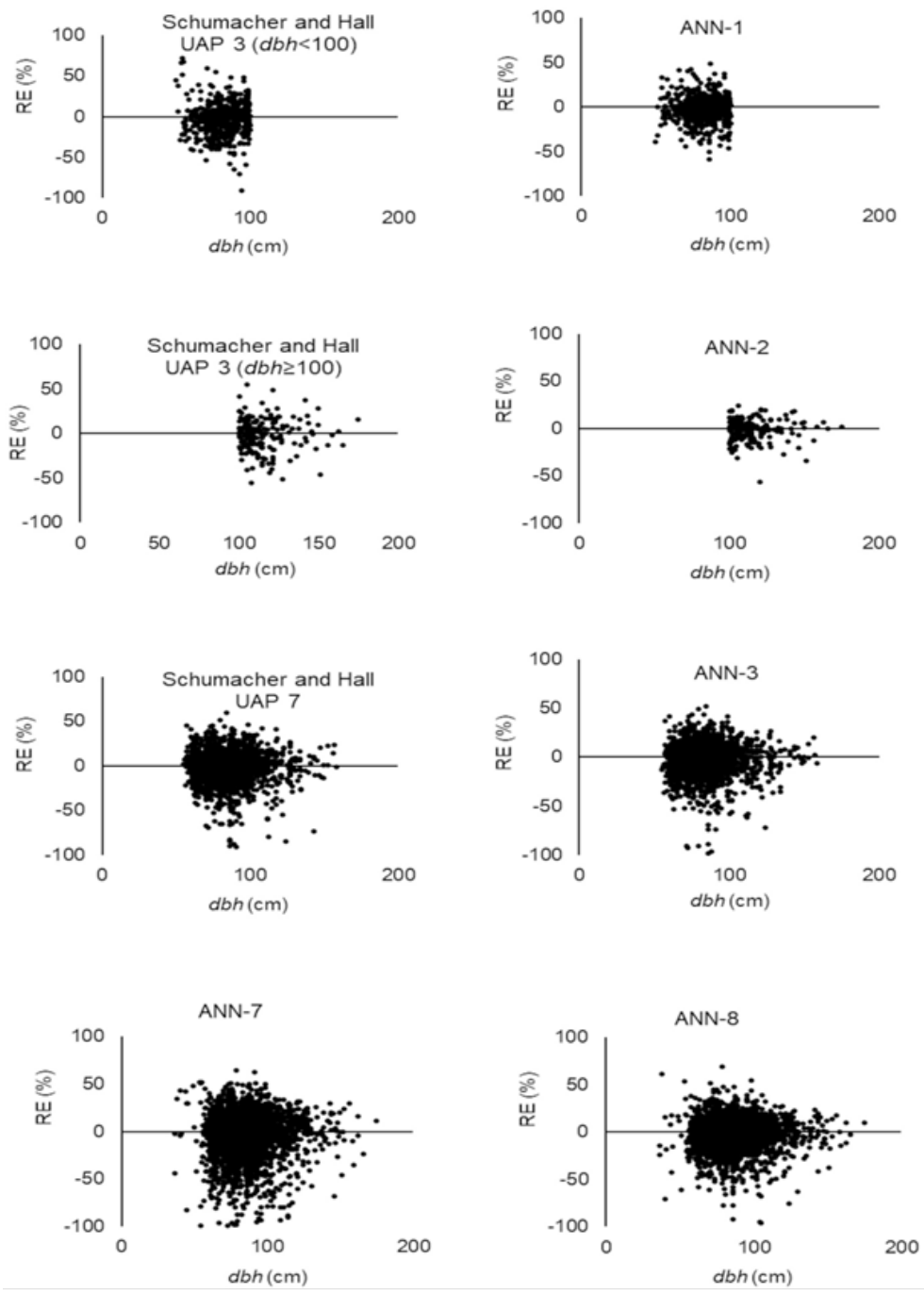

Figure 3. Dispersion of the relative error (RE\%) over the $d b h$ estimates of commercial tree volume in an uneven-aged forest, obtained using the Schumacher and Hall model and artificial neural networks (ANN). 
Figure 4 depicts the frequency distribution of the RE\% classes. We observed that the equation with the highest frequency of RE\% around $\pm 15 \%$ was for the UAP 7 , with $71 \%$. For the ANN, with the ANN-2, $88 \%$ of the RE\% was within $\pm 15 \%$. The ANN- 8 with data from the two UAP presented the frequency of $77 \%$ of the RE\% around $\pm 15 \%$. The ANN with the lowest RE\% frequency around $\pm 15 \%$ was the ANN-7, with $60 \%$ (Figure 4). Therefore, the ANN-2 with the separated data and the ANN-8 with the merged data presented highly satisfactory results.
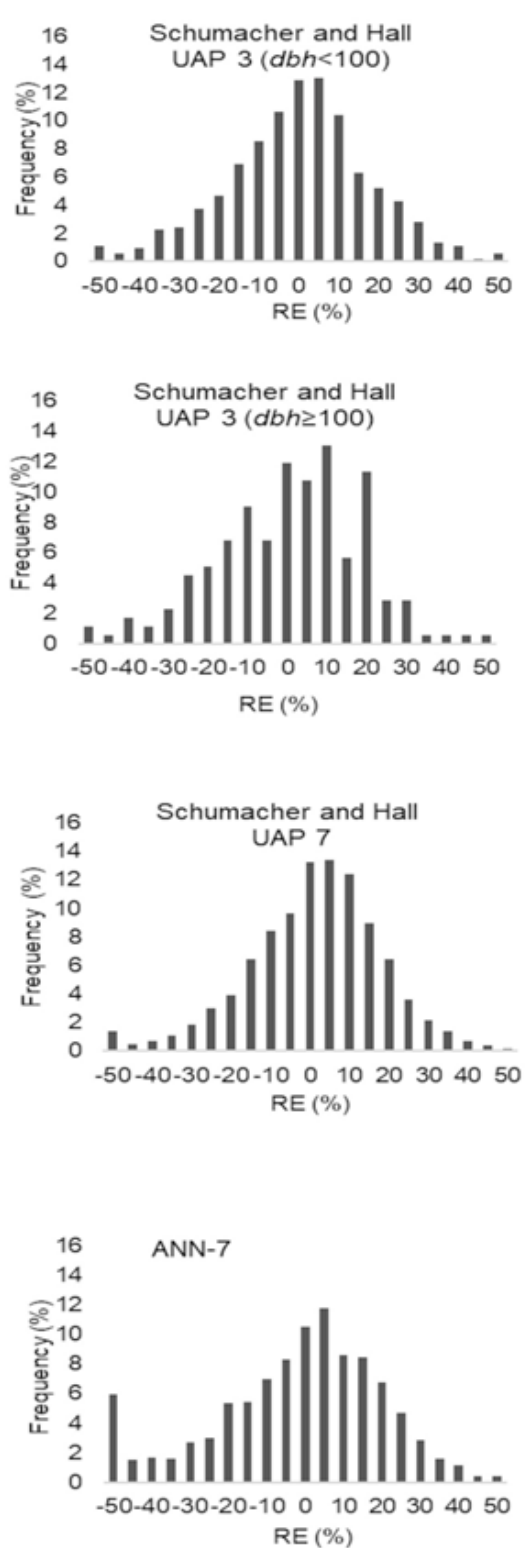
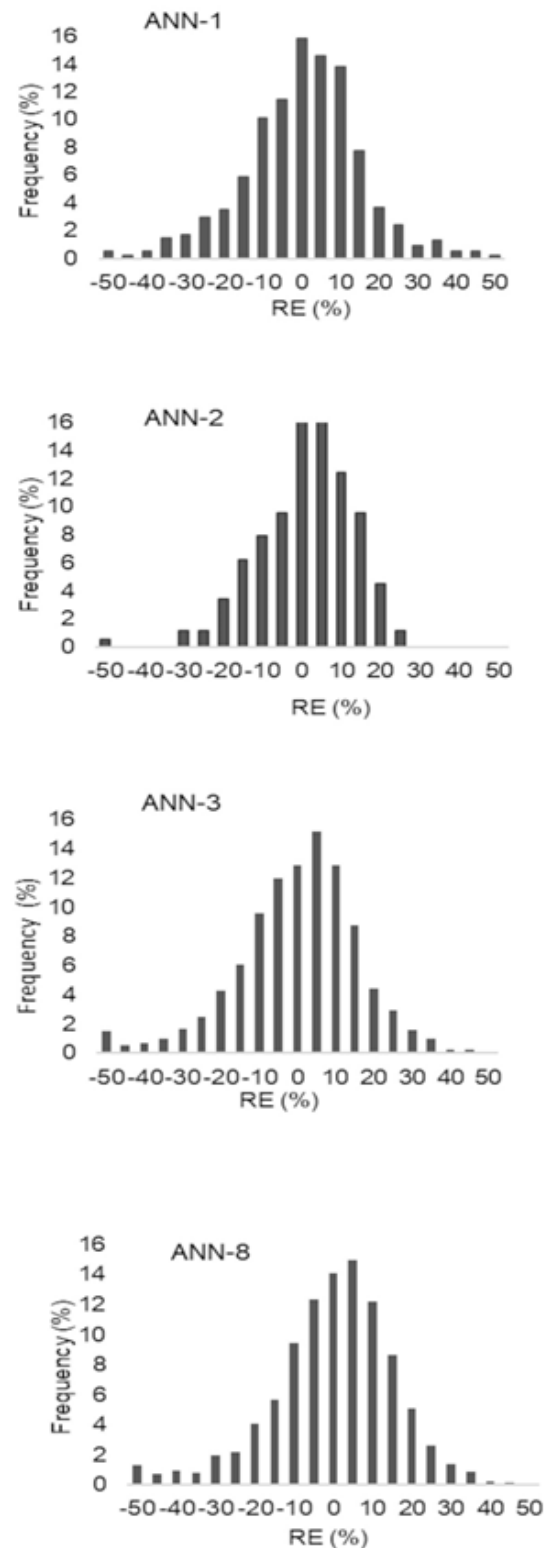

Figure 4. Frequency distributions of the relative error (RE\%) classes for the tree commercial volume estimates in an uneven-aged forest obtained using the Schumacher and Hall model and artificial neural networks (ANN).

ANN has advantages over linear regression models due to factors such as the ability to learn and generalize, tolerance to data noise, and for modeling non-linear relationships between variables (Che et al., 2019). Furthermore, ANN have higher accuracies when predicting volume using smaller samples that represent a cost and time reduction for forest inventory practices (Tavares Júnior et al., 2019).

Even with a restricted database, ANNs are capable of generating more accurate volumetric estimates than regression (Diamantopoulou \& Milios, 2010). Moreover, for linear regression, it 
is necessary to meet statistical assumptions such as normality, homoscedasticity, multicollinearity, and others (Gujarati \& Porter, 2011). The same does not apply for ANN that can benefit from using categorical variables to facilitate the modeling process (Silva et al., 2020).

\section{CONCLUSIONS}

The estimates of commercial tree volume of forest species in the Amazon Forest can be accurately obtained without bias using artificial neural networks (ANNs).

Tree commercial height is a necessary variable for estimating the tree volume in the Amazon Forest using ANN.

A single artificial neural network can be used to predict the commercial volume of trees in the Amazon Forest, not needing data stratification by location and diameter class.

\section{REFERENCES}

Abreu, J. C., Soares, C. P. B., \& Leite, H. G. (2017). Assessing alternatives to estimate the stem volume of a seasonal semi-deciduous forest. Floresta, 47(4), 375-382. http://dx.doi.org/10.5380/rf.v47i4.54259.

Araújo, A. C. S. C., Binoti, M. L. M. S., Leite, H. G., Binoti, D. H. B., Ximenes, L. C., Nogueira, G. S. N., \& Carneiro, J. A. (2015). Artificial neural networks with skip layer connections to estimate the volume of forest formations in the state of Minas Gerais. Australian Journal of Basic and Applied Sciences, 36(9), 319-327.

Binoti, D. H. B., Binoti, M. L. M. S., \& Leite, H. G. (2014a). Configuração de redes neurais artificiais para estimação do volume de árvores. Ciência da Madeira, 5(1), 58-67. http://dx.doi.org/10.12953/21776830.v05n01a06.

Binoti, M. L. M. S., Binoti, D. H. B., Leite, H. G., Garcia, S. L. R., Ferreira, M. Z., Rode, R., \& Silva, A. A. L. (2014b). Redes neurais artificiais para estimação do volume de árvores. Revista Árvore, 38(2), 283288. http://dx.doi.org/10.1590/S0100-67622014000200008.

Campos, J. C. C., \& Leite, H. G. (2017). Mensuração florestal: perguntas e respostas (5. ed., 123 p.). Viçosa: Universidade Federal de Viçosa.

Celentano, D., Sills, E., Sales, M., \& Verissimo, A. (2012). Welfare outcomes and the advance of the deforestation frontier in the Brazilian Amazon. World Development, 40(4), 850-864. http://dx.doi.org/10.1016/j.worlddev.2011.09.002.

Che, S., Tan, X., Xiang, C., Sun, J., Hu, X., Zhang, X., Duan, A., \& Zhang, J. (2019). Stand basal area modelling for Chinese fir plantations using an artificial neural network model. Journal of Forestry Research, 30(5), 1641-1649. http://dx.doi.org/10.1007/s11676-018-0711-9.

Cordeiro, M. A., Pereira, N. N. J., Binoti, D. H. B., Binoti, M. L. M. S., \& Leite, H. G. (2015). Estimativa do volume de Acacia mangium utilizando técnicas de redes neurais artificiais e máquinas vetor de suporte. Pesquisa Florestal Brasileira, 35(83), 255-261. http://dx.doi.org/10.4336/2015.pfb.35.83.596.

Diamantopoulou, M. J., \& Milios, E. (2010). Modelling total volume of dominant pine trees in reforestations via multivariate analysis and artificial neural network models. Biosystems engineering, 105(3), 306-315. https://doi.org/10.1016/j.biosystemseng.2009.11.010.

Espírito-Santo, F. D. B., Shimabukuro, Y. E., Aragão, L. E. O. C., \& Machado, E. L. M. (2005). Análise da composição florística e fitossociológica da floresta nacional do Tapajós com o apoio geográfico de imagens de satélites. Acta Amazonica, 35(2), 155-173. http://dx.doi.org/10.1590/S004459672005000200006.

Gama, J. R. V., Bentes-Gama, M. M., \& Scolforo, J. R. S. (2005). Manejo sustentado para floresta de várzea na Amazônia Oriental. Revista Árvore, 29(005), 719-729. http://dx.doi.org/10.1590/S010067622005000500007.

Gomes, K. M. A., Silva-Ribeiro, R. B., Gama, J. R. V., \& Andrade, D. F. C. (2018). Eficiência na estimativa volumétrica de madeira na Floresta Nacional do Tapajós. Nativa (Sinop), 6(2), 170-176. http://dx.doi.org/10.31413/nativa.v6i2.5237.

Gorgens, E. B., Leite, H. G., Gleriani, J. M., Soares, C. P. B., \& Ceolin, A. (2014). Influência da arquitetura na estimativa de volume de árvores individuais por meio de redes neurais artificiais. Revista Árvore, 38(2), 289-295. http://dx.doi.org/10.1590/S0100-67622014000200009.

Gujarati, D. N., \& Porter, D. C. Econometria básica-5. Amgh Editora, 2011. 
Instituto Brasileiro do Meio Ambiente e dos Recursos Naturais Renováveis - IBAMA. (2004). Plano de Manejo - Floresta Nacional do Tapajós (580 p.). Brasília: IBAMA.

Islam, M. N., Kurttila, M., Mehtätalo, L., \& Haara, A. (2009). Analysing the Effects of Inventory Errors on Holding-Level Forest Plans: the case of measurement error in the basal area of the dominated tree species. Silva Fennica, 43(1), 71-85. http://dx.doi.org/10.14214/sf.218.

Lacerda, T. H. S., Cabacinha, C. D., Araújo Júnior, C. A., Maia, R. D., \& Lacerda, K. W. S. (2017). Artificial neural networks for estimating tree volume in the Brazilian savanna. Cerne, 23(4), 483-491. http://dx.doi.org/10.1590/01047760201723042347.

Leite, H. G., Binoti, D. H. B., Oliveira Neto, R. R., Lopes, P. F., Castro, R. R., Paulino, E. J., Binoti, M. L. M. S., \& Colodette, J. L. (2016). Redes Neurais Artificiais para a estimação da densidade básica da madeira. Scientia Forestalis, 44(109), 149-154. http://dx.doi.org/10.18671/scifor.v44n109.14.

Lopes, L. S. S., Rode, R., Pauletto, D., Baloneque, D. D., Santos, F. G., Silva, A. R., Binoti, D. H. B., \& Leite, H. G. (2020). Uso de regressão e redes neurais artificiais na estimativa do volume de Khaya ivorensis. Ciência da Madeira, 11(2), 74-84. http://dx.doi.org/10.12953/2177-6830/rcm.v11n2p74-84.

Miguel, E. P., Rezende, A. V., Leal, F. A., Matricardi, E. A. T., Vale, A. T., \& Pereira, R. S. (2015). Redes neurais artificiais para a modelagem do volume de madeira e biomassa do cerradão com dados de satélite. Pesquisa Agropecuária Brasileira, 50(9), 829-839. http://dx.doi.org/10.1590/S0100204X2015000900012.

Reis, L. P., Souza, A. L., Mazzei, L., Reis, P. C. M. R., Leite, H. G., Soares, C. P. B., Torres, C. M. M. E., Ruschel, A. R., Silva, L. F., \& Rêgo, L. J. S. (2019). Modeling of tree recruitment by artificial neural networks after wood harvesting in a forest in eastern Amazon rain forest. Ciência Florestal, 29(2), 583-594. http://dx.doi.org/10.5902/1980509825808.

Reis, L. P., Souza, L. S., Reis, P. C. M. R. R., Mazzei, L., Binoti, D. H. B., \& Leite, H. G. (2018). Prognose da distribuição diamétrica na Amazônia utilizando redes neurais artificiais e autômatos celulares. Floresta, 48(1), 93-102. http://dx.doi.org/10.5380/rf.v48i1.52748.

Ribeiro, R. B. S., Gama, J. R. V., \& Melo, L. O. (2014). Seccionamento para cubagem e escolha de equações de volume para a Floresta Nacional do Tapajós. Cerne, 20(4), 605-612. http://dx.doi.org/10.1590/01047760201420041400.

Ribeiro, R. B. S., Gama, J. R. V., Souza, A. L., Leite, H. G., Soares, C. P. B., \& Silva, G. F. (2016). Métodos para estimar o volume de fustes e galhos na floresta nacional do tapajós. Revista Árvore, 40(1), 8188. http://dx.doi.org/10.1590/0100-67622016000100009.

Riedmiller, M., \& Braun, H. (1993). A direct adaptive method for faster backpropagation learning: the RPORP algorithm. In Proceedings of the IEEE International Conference on Neural Networks (pp. 586591). USA: IEEE. http://dx.doi.org/10.1109/ICNN.1993.298623.

Rocha, S. J. S. S. D., Torres, C. M. M. E., Jacovine, L. A. G., Leite, H. G., Gelcer, E. M., Neves, K. M., Schettini, B. L. S., Villanova, P. H., Silva, L. F. D., Reis, L. P., \& Zanuncio, J. C. (2018). Artificial neural networks: modeling tree survival and mortality in the Atlantic Forest biome in Brazil. The Science of the Total Environment, 645, 655-661. PMid:30029140. http://dx.doi.org/10.1016/j.scitotenv.2018.07.123.

Santos, K. N. F., Rode, R., Andrade, D. F. C., Corrêa, K. K. S., \& Lopes, L. S. S. (2018). Ajuste de equações volumétricas e redes neurais artificiais na estimativa do volume de tauari na floresta nacional do Tapajós. Revista Agroecossistemas, 10(1), 1-17. http://dx.doi.org/10.18542/ragros.v10i1.5130.

Scheneider, R. R., Arima, E., Veríssimo, A., Barreto, P., \& Souza Junior, C. (2000). Amazônia Sustentável: limitantes e oportunidades para o desenvolvimento rural. Brasília: Banco Mundial; Belém: Imazon.

Schumacher, F. X., \& Hall, F. S. (1933). Logarithmic expression of timber-tree volume. Journal of Agricultural Research, 47(9), 719-734.

Silva, S., De Oliveira Neto, S. N., Leite, H. G., De Alcântara, A. E. M., De Oliveira Neto, R. R., \& De Souza, G. S. A. (2020). Productivity estimate using regression and artificial neural networks in small familiar areas with agrosilvopastoral systems. Agroforestry Systems, 94(6), 1-17. http://dx.doi.org/10.1007/s10457-020-00526-1.

Sistema Nacional de Informações Florestais - SNIF. (2017). Estoque das Florestas. Serviço Florestal Brasileiro. Retrieved in 2018, January 10, from http://www.florestal.gov.br/snif/recursosflorestais/estoque-das florestas?print=1\&tmpl=component

Tavares Júnior, I. S., Rocha, J. E. C., Ebling, Â. A., Chaves, A. S., Zanuncio, J. C., Farias, A. A., \& Leite, H. G. (2019). Artificial neural networks and linear regression reduce sample intensity to predict the commercial volume of eucalyptus clones. Forests, 10(3), 268. http://dx.doi.org/10.3390/f10030268. 
Thaines, F., Braz, E. M., Mattos, P. P., \& Thaines, A. A. R. (2010). Equações para a estimativa de volume de madeira para a região da bacia do Rio Ituxi, Lábrea, AM. Pesquisa Florestal Brasileira, 30(64), 283289. http://dx.doi.org/10.4336/2010.pfb.30.64.283.

Thomas, C., Andrade, C. M., Schneider, P. R., \& Finger, C. A. G. (2006). Comparação de equações volumétricas ajustadas com dados de cubagem e análise de tronco. Ciência Florestal, 16(3), 319-327. http://dx.doi.org/10.5902/198050981911.

Tonini, H., \& Borges, R. A. (2015). Equação de volume para espécies comerciais em Florestas Ombrófila Densa no sul de Roraima. Pesquisa Florestal Brasileira, 35(82), 111-117. http://dx.doi.org/10.4336/2015.pfb.35.82.738.

Vendruscolo, D. G. S., Chaves, A. G. S., Medeiros, R. A., Silva, R. S., Souza, H. S., Drescher, R., \& Leite, H. G. (2017). Estimativa da altura de árvores de Tectona grandis L.f. utilizando regressão e redes neurais artificiais. Nativa (Sinop), 5(1), 52-58. http://dx.doi.org/10.5935/2318-7670.v05n01a09.

Veríssimo, A., \& Pereira, D. (2014). Produção na Amazônia Florestal: características, desafios e oportunidades. Parcerias Estratégicas, 19(38), 13-44.

Authors' contributions: DVO: Writing - original draft, Conceptualization, Investigation, Data curation; RR: Formal Analysis, Supervision, Writing - review \& editing; RRON: Data curation, Formal Analysis, Software; JRVG: Supervision, Writing - review \& editing; HGL: Software, Supervision, Writing - review \& editing. 